\title{
USING PHOTOS AT THE THEME THE "DANUBE DELTA"
}

\author{
ROXANA TEODORA MATEIU (COTOI) \\ Secondary School No. 1 Românaşi, Sălaj, Romania, e-mail: cotoi_r@yahoo.com
}

\section{LARISA CIUREAN}

"Gh. Lazăr" Pedagogical High School, Zalău, Romania, e-mail: larissaro@yahoo.com

\section{CODIN CIUREAN}

"Gh. Lazăr" Pedagogical High School, Zalău, Romania, e-mail: codin_Ipz@yahoo.com

(Received: April 2014; in revised form: July 2014)

\begin{abstract}
The objective of this study is to analyze from the MSc students' perspective, the task relating to the use of photographs in a subject chosen from the curriculum, the problem-solving process, and its solution. The task was given at the course "Models and Paradigms of Teaching and Learning", at the first year students of the MSc Management of the Curriculum at the Faculty of Psychology and Sciences of Education, in the 2013-2014 academic year. At the end of this study, we concluded that in analyzing and interpreting the content of a photograph with students, we can use various forms of organization or interaction, different teaching methods, and procedures. By solving the task, the MSc students developed their competences of planning learning activities starting from a specific competence and they could use that competence in the pre-university educational system.
\end{abstract}

Keywords: curricular management, learning activities, ecosystem, biocenosis, biotope, biome.

\section{INTRODUCTION}

The objective of this study was to analyze from MSc students' perspective, the task relating to the use of photographs in a subject chosen from the 
curriculum, the problem-solving process, and its solution. The task was given at the course "Models and Paradigms of Teaching and Learning", at the first year students of the MSc Management of the Curriculum at the Faculty of Psychology and Sciences of Education, in the 2013-2014 academic year.

The specific objectives were:

1) analyzing the tasks to be solved;

2) analyzing the solving of tasks;

3) analyzing the process performed by MSc students for solving tasks;

4) analyzing the progress made in developing professional competences by performing these tasks;

5) analyzing the transfer of the result of learning activities and tasks, in the school curriculum.

\section{MATERIAL AND METHOD}

Research content. We analyzed the task given to master students: "Choose a photo that you can use in teaching. Design seven learning activities based on this photo. Work on the document provided as a template. For selfassessment and peer feedback use the attached evaluation grid".

We analyzed the resulting text from solving the task that we made as the authors and the necessary process to reach the final result. We reviewed the progress made in the development of professional competences by performing this issue and how to transfer what we learnt in the activity with students.

The subjects of the research. In this research, a subject of the research was the Professor holder of the course "Models and paradigms of teaching and learning" who proposed the task, provided feedback to master students and evaluated the solving. We received the consent of the owner of the course to analyze the results obtained in this research. The second subject of the research was one of the authors of this study, a Biology and Chemistry teacher at Secondary School No. 1 Românaşi, Sălaj, with 7 years experience in school education.

Research methods. Overall, this qualitative research is a case study. We used the self observation method to study the investigating of self, from both as object and subject of investigation. For data collection, we used the method of action- research and went through several phases: evaluation, diagnosis, planning, implementation, monitoring. We used the narrative method also to collect data (Băban, 2002). For data analysis, we used enumerative analysis, reiterative analysis and subjective analysis when we studied the given task, solving the task and the evaluation grid (Băban, 2002). 


\section{RESULTS}

We present as the main result of the research, the use of pictures (figure 1) on the theme of "The Danube Delta" in the learning activities with students from eighth grade. The specific competences extracted from curriculum, targeted to be achieved by students in the designed learning activities were: 1.1 Identifying the components of an ecosystem; 2.1 Using the appropriate means and methods for exploration/investigation of ecosystems; 3.1 Representing the structure and functions of biological systems based on models; 5.2 Demonstrating understanding of the consequences of their own behaviour in relation to the environment; 5.1 Demonstrating ecological thinking in decision making.

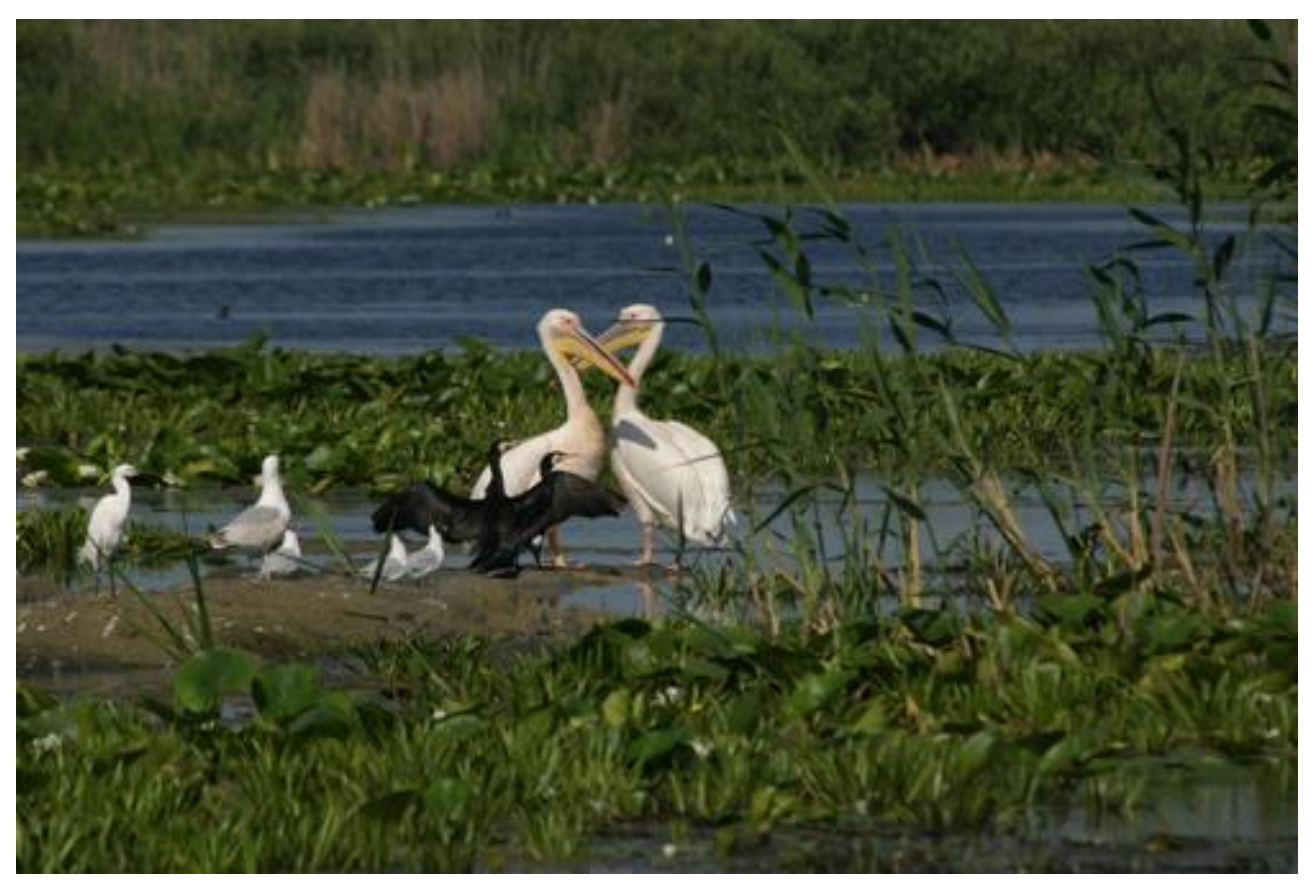

Fig. 1. Ecosystems in the Danube Delta (http://salvatidelta.ro/deltasemper)

\section{Learning activity no. 1}

Theme of the learning activity: The Danube Delta

Specific competence: 2.1 Using the appropriate means and methods for exploration/investigation of ecosystems

Specific aims. Students will be able to:

- Identify abiotic factors from the Danube Delta;

- Analyze biotic factors from the Danube Delta; 
- Describe in a literary manner the Danube Delta ecosystems emphasizing abiotic and biotic factors;

- Describe scientifically the Danube Delta ecosystems emphasizing abiotic and biotic factors.

Classroom interaction: whole class, individually

Teaching aids: the photography "Ecosystems in the Danube Delta".

Methods and techniques: exercise, observation, literary description, and scientific description.

Task no. 1: Work individually for five minutes. Describe in a literary manner the ecosystems in the photo, focusing on the biotic and abiotic factors.

Task no. 2: Work individually for five minutes. Describe scientifically the ecosystems in the photo, focusing on biotic and abiotic factors.

Task no. 3: Work individually for five minutes. Describe in a literary manner the ecosystems in the photo, focusing on the biotic and abiotic factors. Use the following terms: swamp, sand bank, wetlands, water, aquatic plants, birds, reeds, and forests.

Task no. 4: Work individually for five minutes. Describe scientifically the ecosystems in the photo, focusing on biotic and abiotic factors. Use the following terms: ponds, reeds, water, submerged flora, water lilies, water arrow, willow, pelicans, and cormorants.

Activity in front of the class:

Present how you solved the task.

Solving task no. 1: There are several aquatic and terrestrial ecosystems in this photographed area of the Danube Delta. The eye captures an ecosystem of rivers and one of stagnant water, an ecosystem of wetlands and floodplain areas with reeds and reed islet, along with an ecosystem of sand banks. In the background, at the skyline, we barely distinguish the forest ecosystem. In this complex of various ecosystems there are several abiotic factors: water in the river and a pond, the sand bank composed of sand and silt. Without seeing it, we are aware of the presence of air and we can observe the brightness. Among biotic factors, we note firstly, a lot of plants: reed, the water fern, water arrow, water lilies, and willows. In this kingdom of water and plants, there are two majestic pelicans, a few black cormorants, blue cormorants, and a little egret.

Solving task no. 2: In the photo one notes a complex of aquatic and terrestrial ecosystems in the Danube Delta. In the foreground, we can see an ecosystem of banks, which is bordered by swamp and floodplain ecosystem areas with reeds, water lilies and other aquatic plants and an ecosystem of stagnant water. In the second plan we distinguish an ecosystem of rivers. In the background, we see a forest ecosystem dominated by species of poplar. Biotic visible factors are several plants (reed, the water fern, water arrow, water lilies, and willows) and some birds (pelicans, dark and blue cormorants, and a little egret). Abiotic visible 
factors are: the water in the river branch and a pond, and the sand bank composed of sand and silt.

Solving task no. 3:

\begin{tabular}{|l|l|}
\hline \multicolumn{1}{|c|}{ Keywords } & \multicolumn{1}{c|}{ Literary description } \\
\hline $\begin{array}{l}\text { swamp, sand bank, } \\
\text { water, aquatic plants, } \\
\text { birds, reeds, } \\
\text { wetlands, forests }\end{array}$ & $\begin{array}{l}\text { Aquatic ecosystems and terrestrial ecosystems in the Danube } \\
\text { Delta unfold in a mosaic of colours and shapes. The eye captures } \\
\text { an ecosystem of flowing water and one of stagnant water, a } \\
\text { swamp ecosystem with reeds, along with an ecosystem of a sand }\end{array}$ \\
$\begin{array}{l}\text { bank, bordered by aquatic plants. In the background, on the } \\
\text { horizon, we barely distinguish a willow forest ecosystem. In this } \\
\text { complex of various ecosystems we can observe several abiotic } \\
\text { factors: water in the river branch and a pond, a sand bank } \\
\text { composed of sand and silt. Without seeing it, we are aware of the } \\
\text { presence of air and can observe the brightness. Among biotic } \\
\text { factors, we note firstly, a few plants: reed, the water fern, water } \\
\text { arrow, water lilies, and willows. In this kingdom of water, } \\
\text { wetlands, plants and birds, there are two majestic pelicans, a few }\end{array}$ \\
black cormorants, dark blue cormorants, and a little egret.
\end{tabular}

Solving task no. 4:

\begin{tabular}{|l|l|}
\hline \multicolumn{1}{|c|}{ Keywords } & \multicolumn{1}{c|}{ Scientific description } \\
\hline $\begin{array}{l}\text { ponds, reeds, water, } \\
\text { submerged flora, water } \\
\text { lilies, water arrow, willow, } \\
\text { pelicans, cormorants }\end{array}$ & $\begin{array}{l}\text { In the photo one notes a complex of aquatic and terrestrial } \\
\text { ecosystems in the Danube Delta. In the foreground, we can } \\
\text { see an ecosystem of banks, which is bordered by swamp and } \\
\text { floodplain ecosystem areas with reeds, water lilies and other } \\
\text { species of submerged flora and an ecosystem of stagnant } \\
\text { water and ponds. In the second plan, we distinguish an } \\
\text { ecosystem of rivers. In the background, we see a forest } \\
\text { ecosystem dominated by species of poplar. Biotic visible } \\
\text { factors are several plants (reed, the water fern, water arrow, } \\
\text { water lilies, and willows) and some birds (pelicans, dark and } \\
\text { blue cormorants, a little egret). }\end{array}$ \\
\hline
\end{tabular}

Learning activity no. 2

Theme of the learning activity: The Danube Delta

Specific competence: 3.1 Representing the structure and functions of biological systems based on models

Specific aims. Students will be able to:

- Analyze the structure of the Danube Delta ecosystems answering 10 questions in the study guide

- Describe in a literary manner the structure of the Danube Delta ecosystems answering 10 questions in the study guide

- Describe scientifically the structure of the Danube Delta ecosystems answering 10 questions in the study guide

- To interpret the structure of the Danube Delta ecosystems answering 10 questions in the study guide 


\section{Classroom interaction: pair work}

Teaching aids: the photo "Ecosystems in the Danube Delta", the study guide

Methods and techniques: exercise, individual work with the guide, observation, conversation

Task no. 1 Work in pairs for five minutes. Describe in a literary manner the structure of the Danube Delta ecosystems, as you can see in the photo, answering the 10 questions in the study guide.

\begin{tabular}{|c|c|}
\hline Questions & Literary description \\
\hline $\begin{array}{l}\text { 1. What is represented in this } \\
\text { photo? }\end{array}$ & $\begin{array}{l}\text { 1. In the photo we see the Danube Delta, a small } \\
\text { corner of Heaven. }\end{array}$ \\
\hline $\begin{array}{l}\text { 2. What abiotic elements are } \\
\text { observed in this part of the delta? }\end{array}$ & $\begin{array}{l}\text { 2. The water surface is penetrated by a sand bank. } \\
\text { In the distance, above the water, rises another } \\
\text { piece of land. Above this piece of earth lies an } \\
\text { invisible cloak of air. }\end{array}$ \\
\hline $\begin{array}{l}\text { 3. What is the prevailing colour in } \\
\text { this area of the delta during } \\
\text { summer? }\end{array}$ & 3. During summer, the Delta is a green paradise. \\
\hline $\begin{array}{l}\text { 4. What do you see in the } \\
\text { foreground? }\end{array}$ & $\begin{array}{l}\text { 4. In the foreground of the photograph, we see } \\
\text { lilies, water arrows and other floating plants. }\end{array}$ \\
\hline $\begin{array}{l}\text { 5. What other plants are observed } \\
\text { in this part of the delta? }\end{array}$ & $\begin{array}{l}\text { 5. A very large area is covered with reeds. Off the } \\
\text { water, the floating carpet is completed by white and } \\
\text { yellow lilies. On the horizon, lies a forest of poplars } \\
\text { and willows. }\end{array}$ \\
\hline $\begin{array}{l}\text { 6. What do you see in the } \\
\text { background? }\end{array}$ & $\begin{array}{l}\text { 6. In the background of the photo we can see a few } \\
\text { birds. }\end{array}$ \\
\hline $\begin{array}{l}\text { 7. Where are the birds in the photo } \\
\text { placed? }\end{array}$ & $\begin{array}{l}\text { 7. The birds are placed on the highest surface of } \\
\text { the sand bank. }\end{array}$ \\
\hline $\begin{array}{l}\text { 8. What birds do you notice on the } \\
\text { sand bank? }\end{array}$ & $\begin{array}{l}\text { 8. Two pelicans, a few cormorants and egrets are } \\
\text { resting on the surface of the sand bank. }\end{array}$ \\
\hline $\begin{array}{l}\text { 9. How many birds are lit by the } \\
\text { sun? }\end{array}$ & 9. The nine birds enjoy the warmth of the sun. \\
\hline $\begin{array}{l}\text { 10. What colours are the birds in } \\
\text { the photo? }\end{array}$ & $\begin{array}{l}\text { 10. Birds have monochromatic feathers, a } \\
\text { combination of black and white. }\end{array}$ \\
\hline
\end{tabular}

Task no. 2 Work in pairs for five minutes. Describe scientifically the structure of the Danube Delta ecosystems, as you can see in the photo, answering the 10 questions in the study guide.

\begin{tabular}{|c|c|}
\hline Questions & Scientific description \\
\hline $\begin{array}{l}\text { 1. What biome is represented in the } \\
\text { photo? }\end{array}$ & $\begin{array}{l}\text { 1. In the photo is represented the Danube Delta, a } \\
\text { biome consisting of several ecosystems. }\end{array}$ \\
\hline $\begin{array}{l}\text { 2. Which are the Danube Delta } \\
\text { ecosystems visible in the photo? }\end{array}$ & $\begin{array}{l}\text { 2. The Danube Delta ecosystems visible in the } \\
\text { photo are: river ecosystem, stagnant water } \\
\text { ecosystems, wetlands and floodplain ecosystem } \\
\text { areas with reeds, sand bank ecosystem, poplar } \\
\text { and willow forest ecosystem. }\end{array}$ \\
\hline
\end{tabular}


3. Which are the components of the biotope visible in the photo?

4. Which are the biocenosis components visible in the photo?

5. What plant species can you notice around the sand bank?

6. Which plant species are observed in the background?

7. What types of plants are observed taking into consideration their living environment?

8. What species of birds do you see?

9. How do you explain that birds of different species are on the same sand bank?

10. What do lilies tell you concerning the depth and salinity of the water?
3. Components of the biotope visible in the photo are: water, sand and mud from the sand bank.

4. Visible components of biocenosis are numerous plants and animals.

5. Around the sand bank, one can notice the following plant species: white waterlily (Nymphaea alba), yellow waterlily (Nuphar lutea), and reed (Phragmites australis).

6. In the background we see: willow, poplar, alder, and ash.

7. According to their living environment, one can notice two types of aquatic plants: floating plants and submerged plants.

Aquatic plants in the foreground are: reeds and water lilies. In the background there are terrestrial plants: poplar, willow, alder, and ash.

8. We note the following species of birds: pelicans (Pelecanus onocrotalus), cormorant (Phalacrocorax pygmaeus), a little egret (Egretta garzetta), and gulls (Larus argentatus).

9. Birds of different species are on the same sand bank, as there are small areas of land there and because they are not enemies.

10. Lilies indicates that the water is sweet and not very deep.

Task no. 3: Work in pairs for five minutes. Analyze the structure of the Danube Delta ecosystems, as you can see in the photo, answering the 10 questions in the study guide.

\begin{tabular}{|c|c|}
\hline $\begin{array}{c}\text { Questions concerning the analysis of the } \\
\text { photo content }\end{array}$ & Analysis of the photo content \\
\hline 1. What biome does the photo capture? & $\begin{array}{l}\text { 1. The picture captures the biome of the } \\
\text { Danube Delta. }\end{array}$ \\
\hline $\begin{array}{l}\text { 2. What plant species do you notice } \\
\text { around the sand bank? }\end{array}$ & $\begin{array}{l}\text { 2. Around the sand bank we notice the } \\
\text { following plant species: white waterlily } \\
\text { (Nymphaea alba), yellow waterlily (Nuphar } \\
\text { lutea), and reed (Phragmites australis). }\end{array}$ \\
\hline $\begin{array}{l}\text { 3. What plant species are observed in the } \\
\text { background? }\end{array}$ & $\begin{array}{l}\text { 3. In the background we see willow, poplar, } \\
\text { alder, and ash. }\end{array}$ \\
\hline $\begin{array}{l}\text { 4. What types of plants can be noticed } \\
\text { taking into consideration their living } \\
\text { environment? }\end{array}$ & $\begin{array}{l}\text { 4. According to their living environment, we } \\
\text { notice the following types of aquatic plants: } \\
\text { floating plants and submerged plants. }\end{array}$ \\
\hline 5. What species of birds do you see? & $\begin{array}{l}\text { 5. We note the following species of birds: } \\
\text { pelicans (Pelecanus onocrotalus), cormorant } \\
\text { (Phalacrocorax pygmaeus), a little egret } \\
\text { (Egretta garzetta), and gulls (Larus } \\
\text { argentatus). }\end{array}$ \\
\hline 6. What abiotic elements do you notice? & $\begin{array}{l}\text { 6. We note the following abiotic elements: } \\
\text { sand bank, sand, water, and air. }\end{array}$ \\
\hline
\end{tabular}




\begin{tabular}{|l|l|}
\hline $\begin{array}{l}\text { 7. What kind of water do you see? } \\
\text { 8. In what season was the photo taken? }\end{array}$ & $\begin{array}{l}\text { 7. We observe a stream and a pond. } \\
\text { 8. This photo was taken in summer. } \\
\text { 9. What is the predominant colour? }\end{array}$ \\
$\begin{array}{l}\text { 10. What are the Danube Delta } \\
\text { ecosystems visible in the photo? }\end{array}$ & $\begin{array}{l}\text { 10. Ecosystems of the Danube Delta visible in } \\
\text { the photo are: the ecosystem of rivers, } \\
\text { stagnant water ecosystems, wetlands and the } \\
\text { floodplain ecosystem areas with reeds, the } \\
\text { sand banks ecosystem, and the poplar and } \\
\text { willow forest ecosystem. }\end{array}$ \\
\hline
\end{tabular}

Task no. 4: Work in pairs for five minutes. Interpret the structure of the Danube Delta ecosystems, as you can see in the photo, answering the 10 questions in the study guide.

\begin{tabular}{|c|}
\hline $\begin{array}{l}\text { Questions concerning the interpretation } \\
\text { of the photo content }\end{array}$ \\
\hline $\begin{array}{l}\text { 1. How do you explain that birds of } \\
\text { different species are on the same sand } \\
\text { bank? }\end{array}$ \\
\hline $\begin{array}{l}\text { 2. What do water lilies tell you about } \\
\text { the depth of the water? }\end{array}$ \\
\hline $\begin{array}{l}\text { 3. What do water lilies tell you about } \\
\text { the salinity? }\end{array}$ \\
\hline $\begin{array}{l}\text { 4. What do reed tell you concern } \\
\text { presence of water? }\end{array}$ \\
\hline
\end{tabular}

5. How do you explain the formation of swamps inside the delta?

6. How do you think these birds feed?

7. What is the relationship between lilies and their environment?

8. How do you explain that in a relatively small area of the delta there are so diverse ecosystems?

9. How do you explain the formation of the sand bank?

10. What is the relationship between pelicans and their environment?
Interpretation of the photo content

1. Birds of different species are on the same sand bank as there are small areas of land and because they are not enemies.

2. Lilies indicate that the water is not very deep.

3. Lilies indicate that the water is sweet.

4. Reed indicates that there is shallow water, which can sometimes dry up.

5. The swamps are formed in some places in the Delta, where water stagnates. The intake of water (precipitation, groundwater, flood, etc.) exceeds evaporation. The fact that the water depth is not big helps growing hydrophilic plants such as reeds.

6. The birds are carnivoures. They feed with: small fish, leeches, crustaceans, worms, and insects.

7. Water lilies are perennial plants that live in ponds, lakes, and streams. They have long stems (rhizomes) stuck in the mud. Their leaves are of two types: a type of underwater leaves and heart-shaped leaves, with a long petiole, floating on the water surface because of some airtubes.

8. On a relatively small area of the delta ecosystems are so diverse because environmental conditions vary greatly on small surfaces.

9. The sand bank was formed by depositing alluvia in the minor riverbed or on its edge.

10. Pelicans have a long beak with a yelloworange bag underneath it for storing the fish they caught. They feed also with sick fish, being considered the "sanitary birds" of the delta. 


\section{Learning activity no. 3}

Theme of the learning activity: The Danube Delta

Specific competence: 1.1 Identifying the components of an ecosystem

Specific aims. Students will be able to identify the components of some ecosystems from the Danube Delta

Classroom interaction: the whole class

Teaching aids: the photography "Ecosystems in the Danube Delta"

Methods and techniques: catechetical conversation and heuristic conversation

The Activity

Catechetical conversation:

- What species of birds do you observe in the photo?

- Where are the birds positioned in the photo?

- How many pelicans are there on the sand bank?

- How many cormorants are there on the sand bank?

- What plant species do you notice around the sand bank?

- What plant species can be observed in the background?

- What abiotic elements do you notice?

- What types of hydrographic units do you notice?

\section{Heuristic conversation:}

- The biotope is a living environment with relatively homogeneous characteristics which develops biocenosis. The biotope structure includes inorganic substances, geographical and mechanical factors, physical and physico-chemical factors, and the relationships between these factors. Observe the picture! What do you think are the inorganic substances that are part of these biotopes? (water, sand, air - oxygen, nitrogen, carbon dioxide, etc.)

- Observe the picture! What geographical factors do you think are specific to these biotopes? (... wide river meadow, small inclination of relief, relatively low altitude, the minor riverbed has a big depth and width, the sand bank consists of sand and silt, bordered by water, shallow water ponds, etc.)

- Observe the picture! What physical factors do you think are characteristic to these biotopes? (... transparency of the water, the water depth, water running speed, water temperature, etc.) 
- Observe the picture! What physico-chemical factors do you think are characteristic to these biotopes? (... salinity of the water, the $\mathrm{pH}$ of the water.)

- We know that the biotope structure determines the configuration of the ecosystem. It can be characterized by different types of environments: continental, insular, edaphic, aquatic, etc. What kind of environments do you notice in this photo? (... island environments, aquatic environments.)

- We know that biocenosis is a biological association of plant and animal organisms that live in a particular environment or sector in the biosphere, forming together a coherent whole, that is in a dynamic equilibrium dependent on the environment. What kind of biocenoses are there in the visible biotopes from the photo? (... A biocenosis characteristic of flowing water, a biocenosis characteristic of sand banks, a biocenosis characteristic of ponds, etc.)

- The ecosystem is the structural unit which is established between a biotope and a biocenosis. You have identified several biotopes and you specified that each has a characteristic biocenosis, so each is an ecosystem. Which are these ecosystems? (... the sand banks ecosystem, the ecosystem of stagnant water: lakes, flood patches, canals and brooks bogged down, the wetlands and flood plains ecosystem - the reed and floating reed islet; the flowing water ecosystem, the ecosystem of floodplain forests (poplar and willow forests).

- These natural ecosystems form a complex of ecosystems, called biome.

\section{Learning activity no. 4}

Theme of the learning activity: Ecosystems in the Danube Delta

Specific competence: 3.1 Representing the structure and functions of biological systems based on models

Specific aims. Students will be able to: photo;

- Explain the structure of the Danube Delta ecosystem visible in the

- Represent the structure of the Danube Delta ecosystem visible in the photo.

Classroom interaction: the whole class, pair work

Teaching aids: the photography "Ecosystems in the Danube Delta"

Methods and techniques: explanation

\section{The Activity}

Teacher explanation: The ecosystem is the structural unit which is established between a biotope and a biocenosis. The biotope represents the totality of present abiotic factors in a particular area of life, that ensures the existence of a community of creatures. It is also the living environment with relatively homogeneous ecological characteristics that develops a biocenosis (DEX, 2009). It is the geographical environment where a group of plants 
and animals lives in homogeneous conditions (NODEX, 2002). It is the limited environment, with particular living conditions and their own appearance, including all bodies which form a biocenosis (Dictionary of Neologisms, 1986). The biotope structure includes inorganic substances, geographical and mechanical factors, physical or physico-chemical factors, and the relationships between these factors. The biotope structure determines the configuration of the ecosystem, which can be characterized by different types of environments: continental, insular, edaphic, aquatic, etc.

Biocenosis is a community of plant and animal organisms that live in a particular environment or sector in the biosphere (DEX, 2009); it is a biological association of plants that are in a dynamic equilibrium dependent on the environment (DEX, 1998). It includes all the living organisms that inhabit a particular environment, forming together a coherent whole (NODEX, 2002). The community of populations of plants, animals, microorganisms, characteristic of a particular biotope, which develop interspecific relationships, is called biocenosis.

We observe that, in the delta, on a small area, environmental conditions change from one place to another. In the foreground we observe a sand bank. Around it we notice that water is stagnant, shallow, so it can be a pond or a swamp. We realize that water is not deep because of the water lilies, the reeds, of the water arrow, and these plants being rooted in the ground covered with water. In the second plan, there is deeper water, so it could be a lake, a canal or a branch of the Danube. In the background, we see another sand bank, but it is not permanently covered by water. We know this because it is covered with poplar and willow forests.

From the biocenosis, we observe in the photo certain plants: White lily (Nymphaea alba), Yellow Water-lily (Nuphar lutea), and reed (Phragmites australis). From biocenosis we also notice migratory birds, like the pelican (Pelecanus onocrotalus), the cormorant (Phalacrocorax pygmaeus), egrets (Egretta garzetta) and sedentary birds: gulls (Larus argentatus). The birds are adapted to this living environment by: interdigital membrane which helps them swim, beak shape (e.g. long beak to reach the bottom of the water, with the underneath bag at pelicans to store fish).

In conclusion, we observe more ecosystems in the photo of the Danube Delta. In the foreground: the sand banks ecosystem, the ecosystem of stagnant water (lakes, flood patches, canals, and brooks bogged down), the wetlands and flood plains ecosystem (the reed and floating reed islet); in the second plan, the ecosystem of flowing waters, and in the third plan, the floodplain forest ecosystem (poplar and willow). These natural ecosystems form a complex called biome.

Task: Work in pairs for five minutes. Represent in a bunch type chart the structure and functions of biological systems identified in the photo.

\section{Learning activity no. 5}

Theme of the learning activity: Ecosystems in the Danube Delta 


\section{Specific competence: 1.1 Identifying the components of an ecosystem}

Specific aims: Students will be able to identify the abiotic and biotical elements of the Danube Delta

Classroom interaction: the whole class, group work

Teaching aids: the photography "Ecosystems in the Danube Delta"

Methods and techniques: I know - I want to know - I'm learning, independent study / reading / independent work, exercise, conversation.

Task no. 1: Write for a minute in the first column, the abiotic and biotic components of the Danube Delta that you notice in the picture. I will take one item from everyone and I will write it in the table on the board.

Task no. 2: Write for a minute, in the second column, questions about what you want to know about the abiotic and the biotic components of the Danube Delta that you notice in the picture. I will take one question from each and write it in the table on the board.

Task no. 3: Read the text in Annex 1. Write in the third column answers to the questions in the second column. We discuss together the answers.

\begin{tabular}{|c|c|c|}
\hline I know & I want to know & I am learning \\
\hline $\begin{array}{l}\text { - water canal } \\
\text { - lake } \\
\text { - pond } \\
\text { - pelican } \\
\text { - egret } \\
\text { - waterlily } \\
\text { - willow } \\
\text { - reed }\end{array}$ & 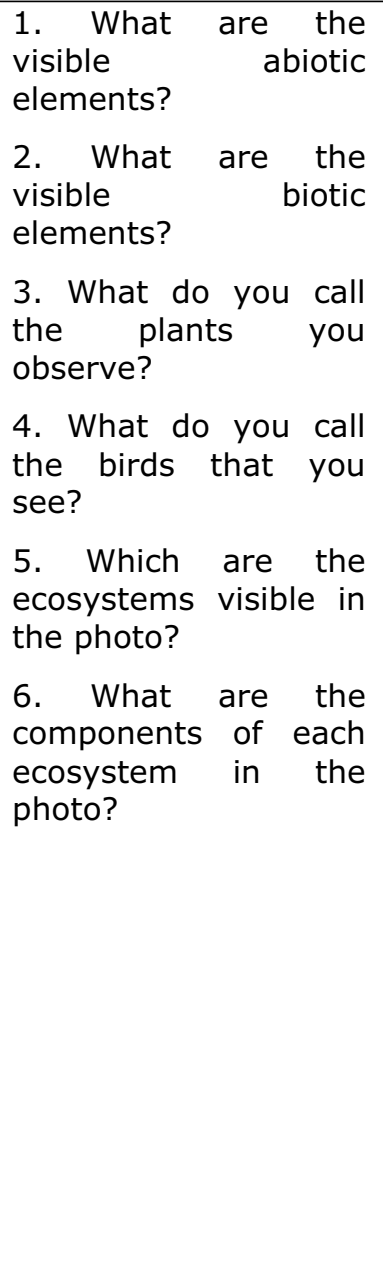 & $\begin{array}{l}\text { 1. The visible abiotic elements are: water, } \\
\text { sand from the sand bank. } \\
\text { 2. The visible biotic elements are plants and } \\
\text { animals. } \\
\text { 3. The plants that we see are: white } \\
\text { waterlilies (Nymphaea alba), yellow } \\
\text { waterlilies (Nuphar lutea), water arrows } \\
\text { (Sagittaria sagittifolia), willows (Salix alba, } \\
\text { Salix fragilis), poplars (Populus alba, Populus } \\
\text { canescens), and alders (Alnus glutinosa). } \\
\text { 4. The birds that we see are: white pelicans } \\
\text { (Pelecanus onocrotalus), cormorants } \\
\text { (Phalacrocorax pygmaeus), egrets (Egretta } \\
\text { garzetta), and gulls (Larus argentatus). } \\
\text { 5. The ecosystems visible in the photo are: } \\
\text { the sand banks ecosystem, the ecosystem of } \\
\text { stagnant water (lakes, flood patches, canals, } \\
\text { and brooks bogged down), the ecosystem of } \\
\text { wetlands and floodplains (the reed and } \\
\text { floating reed islet), the flowing water } \\
\text { ecosystem, the ecosystem of floodplain } \\
\text { forests (poplar and willow). } \\
\text { 6. The components visible in the photo of the } \\
\text { sand banks ecosystem are alluvial deposits of } \\
\text { sand and silt and grassy plants developed in } \\
\text { sand. } \\
\text { The components visible in the photo of the } \\
\text { stagnant water ecosystem are: water, } \\
\text { animals and plants in water (water lilies, } \\
\text { reeds, and water arrows). }\end{array}$ \\
\hline
\end{tabular}




\begin{tabular}{|l|l|}
\hline \multirow{5}{*}{} & $\begin{array}{l}\text { The components of the ecosystem of } \\
\text { wetlands areas and floodplains are: water, } \\
\text { silt from the bottom, animals, and plants } \\
\text { (lilies, reeds, and water arrows). } \\
\text { The components of the ecosystem of flowing } \\
\text { waters are: water and the banks of the minor } \\
\text { bed. } \\
\text { The floodplain forest ecosystem components } \\
\text { are: the land area (the island), poplars and } \\
\text { willows of the floodplain. }\end{array}$ \\
\hline
\end{tabular}

The Danube Delta is a unique area in Europe due to the richness and variety of plants and animals. It is the paradise of birds and fish. Various birds live in the delta: spoonbills, cranes, wild ducks and geese, cormorants, egrets, swans, pelicans, etc. Small animals live in waters: shellfish, water spiders, frogs, water snakes, and fish. The 60 fish species are food for human, birds and animals. Bushes and forests are home to mammals: otters, minks, foxes, and wild boars. In the Delta, there is a large area covered with reeds $(240,000 \mathrm{ha})$. This forms on the water surface floating islands $(0.6-2 \mathrm{~m})$. Off the water, the floating carpet is completed by white and yellow water lilies, duckweed, green algae, etc. Plants grow also in the deep water (water plague, a kind of fern) and there is where aquatic creatures (crayfish, snails, leeches, insect larvae, clams, water snakes, and frogs) find shelter and food. As a complex living environment, the Danube Delta provides food for animals and humans. Mammals (rabbits, wild boars, foxes, and otters) and birds (ducks and wild geese) are hunted for meat, skin, fur, horns, and feathers. For the protection of animals, hunting is prohibited in certain periods of the year (especially during the breeding of mammals and birds). To protect fish species (especially the black spawning fish and that are very expensive: sturgeons, sterlets, sevrugas, Danube-sturgeons) fishing is prohibited during the period the fish lay eggs.

\section{Learning activity no. 6}

Theme of the learning activity: The Danube Delta, a Biosphere reserve

Specific competence: 5.1 Demonstrating ecological thinking in decision making

Specific aims: Students will be able to:

- Describe the living environment of animals, visible in the Danube Delta

- Analyze the components of the ecosystem

- Compare the levee ecosystem with ecosystem of wetlands areas and floodplains (the reed)

- Associate the biocenosis of the Danube Delta with the related areas

- Identify those features of ponds favourable for plants and animals and vulnerable to human actions

- Give reasons why the Danube Delta must be protected and preserved.

Classroom interaction: individually, group work

Teaching aids: the photography "Ecosystems in the Danube Delta" learning

Methods and techniques: the cube, individual study, cooperative 
Task: Use the cube method. Observe the picture. Work in groups of four. Each group will solve the task on one face of the cube.

\begin{tabular}{|c|c|}
\hline Tasks & Solving the tasks \\
\hline $\begin{array}{l}\text { Describe the living } \\
\text { environment of animals, } \\
\text { visible in the Danube Delta. }\end{array}$ & $\begin{array}{l}\text { The living environment of the animals of the delta consists } \\
\text { of lakes and canals, river banks made up of sand and silt, } \\
\text { interposed by floodplain wetlands, reed, willow and poplar } \\
\text { covered areas. }\end{array}$ \\
\hline $\begin{array}{l}\text { Analyze the components of } \\
\text { the ecosystem of wetlands } \\
\text { areas and floodplains visible } \\
\text { in the photo. }\end{array}$ & $\begin{array}{l}\text { The ecosystem of wetlands areas and floodplains in the } \\
\text { photo includes biotopes and biocenosis. The biotope } \\
\text { includes water and alluvial deposits on the bottom. The } \\
\text { biocenosis includes animal associations (we do not see } \\
\text { crayfish, snails, leeches, insect larvae, clams, water } \\
\text { snakes, and frogs) and associations of plants (lilies, reeds, } \\
\text { and water arrows). }\end{array}$ \\
\hline \multirow{3}{*}{$\begin{array}{l}\text { Compare the levee } \\
\text { ecosystem with ecosystem } \\
\text { of wetlands areas and } \\
\text { floodplains (the reed) from } \\
\text { the Delta, visible in the } \\
\text { photo. }\end{array}$} & $\begin{array}{l}\text { The similarities are: both are supported by sand and silt; } \\
\text { both may be flooded. }\end{array}$ \\
\hline & $\begin{array}{l}\text { Differences of the biotopes: the water is deep on the sand } \\
\text { bank (ground water), in the swamp it is above the sand } \\
\text { and silt. }\end{array}$ \\
\hline & $\begin{array}{l}\text { Differences in the biocenosis: on the sand banks grow } \\
\text { herbaceous plants specific to sands, but also hydrophilic } \\
\text { plants (poplar, ash, alder, and willow). }\end{array}$ \\
\hline $\begin{array}{l}\text { Associate the biocenosis of } \\
\text { the Danube Delta with the } \\
\text { related areas. }\end{array}$ & $\begin{array}{l}\text { The biocenosis in the Danube Delta is divided into areas: } \\
\text { reed, floating plants, submerged plants, the area of the } \\
\text { bottom. }\end{array}$ \\
\hline \multirow[t]{4}{*}{$\begin{array}{l}\text { Identify those features of } \\
\text { ponds favourable for plants } \\
\text { and animals and vulnerable } \\
\text { to human actions. }\end{array}$} & $\begin{array}{l}\text { The small depth of water. Ponds are less deep water } \\
\text { accumulations than lakes. Some plants stick their roots in } \\
\text { the soil at the bottom of the pond. The water level in the } \\
\text { delta increases during floods. If the water level rises, some } \\
\text { of the plants can be covered with water. }\end{array}$ \\
\hline & $\begin{array}{l}\text { Transparency. Light penetrates to the bottom, allowing the } \\
\text { development of vegetation. In summer, the phenomenon of } \\
\text { "water blooms" appear. Flood water loses its transparency } \\
\text { when it is polluted with various substances. }\end{array}$ \\
\hline & $\begin{array}{l}\text { Water temperature. The water is heated to the bottom by } \\
\text { the sun rays. Water can be contaminated with hot water } \\
\text { from some factories. }\end{array}$ \\
\hline & $\begin{array}{l}\text { Water salinity. The water in the pond is sweet, with salt } \\
\text { content below } 1 \mathrm{~g} / \mathrm{l} \text {. The water may be polluted by various } \\
\text { substances which originate from factories, from the sewer. } \\
\text { Water can be contaminated with organic substances from } \\
\text { animal farms, slaughterhouses, etc. }\end{array}$ \\
\hline \multirow{2}{*}{$\begin{array}{l}\text { Give reasons } \text { why the } \\
\text { Danube Delta must be } \\
\text { protected and preserved. }\end{array}$} & $\begin{array}{l}\text { 1. The Delta mentained a high biodiversity, a large number } \\
\text { of species from a wide variety of systematic units. }\end{array}$ \\
\hline & $\begin{array}{l}\text { 2. The Danube Delta strikes because of the great density of } \\
\text { many species that are rare or absent in other parts of the } \\
\text { continent, although, due to human activities over the last } \\
\text { few decades, the number of these species and their } \\
\text { habitats have been severely affected. }\end{array}$ \\
\hline
\end{tabular}




\section{Learning activity no. 7}

Theme of the learning activity: Conservation and Protection of the Danube Delta

Specific competence: Demonstrating understanding of the consequences of their own behaviour in relation to the environment

Specific aims: Students will be able to specify the consequences of personal actions in the Danube Delta (the hunting of birds, breaking water lilies, cultivating land, and building a hostel)

Classroom interaction: individually, group work

Teaching aids: the photography "Ecosystems in the Danube Delta" learning.

Methods and techniques: the quadrants/dials method, cooperative

Task: Observe the picture! Work in groups of four. Each group will solve the task of a dial.

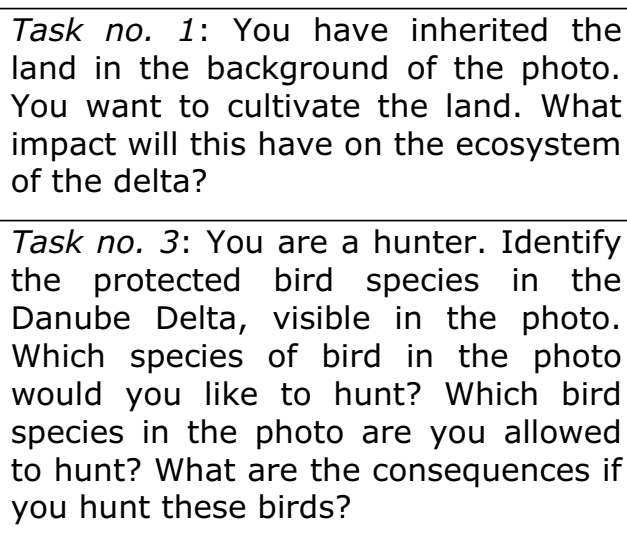

Task no. 3: You are a hunter. Identify the protected bird species in the Danube Delta, visible in the photo. Which species of bird in the photo would you like to hunt? Which bird species in the photo are you allowed to hunt? What are the consequences if you hunt these birds?

Task no. 2: You have bought the land in the background of the photo. You want to build a guesthouse. What impact will this have on the ecosystem of the delta?

Task no. 4: You visit the Danube Delta. You are rowing your boat near water lilies in the photo. A villager makes a necklace from a white water lily. What are the consequences if every visitor agrees to accept a necklace from a white water lily?

\section{DISCUSSIONS AND CONCLUSIONS}

\section{1) Analyzing the tasks to be solved}

We were given the task to design seven learning activities based on a photo of our choice. The professor gave us a template on which to project each activity. At each activity the professor specified the teaching method to be used, and we had the freedom to choose the picture, the subject of activity, the class, specific competences in the curriculum, the organization of the work or interaction. Depending on the chosen elements, we should compose the operational objectives, the task and solve the task given to students.

At the first learning activity, we were required to use the method of literary description and scientific description in two versions: one in which the texts are freely created based on the photograph and one in which the texts are created based on given terms. At the learning activity number two, we were required to use multiple teaching methods and techniques: the study guide, the exercise, and conversation. The requirement was to 
make up 10 questions on which students describe in a literary manner what they see in the photo, 10 questions on which students to describe scientifically what they see in the photo, 10 questions aimed at analyzing the photograph, and 10 questions concerning its interpretation. We were supposed also, to formulate answers to questions.

In the third learning activity, we were required to use catechetical conversation and, separately, heuristic conversation, that is, to formulate questions and correct answers to these questions based on this photo. In the learning activity number four, it was required to use the explanation method as teacher-centred method, and that means that we had to compose a text that explains what is shown in the photo.

In learning activity number five, we were asked to use the method or model of structuring the lesson I know - I want to know - I'm learning. Observing this method, the teaching techniques were individual study or reading, exercise, and conversation. We were asked to design the given task for each step of the method and to fill in the table, taking into consideration the content of the photo. We were asked to devise the text in which students could find some of the information they needed.

In learning activity number six, we were asked to use the cube method. The teaching methods were the individual study or reading and cooperative learning. We were asked to design the tasks on each face of the cube, related to the photography and to solve them. In the learning activity number seven, we were required to use the dials method and the teaching procedure cooperative learning. We were asked to formulate the tasks in each quadrant, related to the photography and to solve them.

In these tasks, based on a photo, we were asked to use different methods and different forms of interaction, which determined us to develop our level of competence in designing learning activities. The given tasks were interesting and challenging.

2) Analyzing the solving of the given tasks. While planning all these learning activities, it was important to have a logical connection between the subject, specific competence, operational objectives or aims, the method used, the task given, the development of the activity, and the expected results following the learning activity.

At the first learning activity, to link the subject of activity with the task, objectives and target competence, we mentioned at each task that the description should be performed by students, highlighting biotic and abiotic factors in the ecosystem of the photo, which was appreciated during assessment. The professor noticed that we had chosen very well the picture to solve the given tasks. The first draft was shorter, it contained information about aspects that were not visible in the photo or unrelated to items identified in the photo. In the second draft, due to the feedback received from the professor, we highlighted several issues that were visible in the photo. The third series of descriptions represented more accurately what was in this picture.

In learning activity number two, the task asked students to describe in a literary manner or scientifically, then analyze and interpret the content of the photography guided by questions in the study guide. After the feedback provided by the professor, we rephrased the aims, ensuring that 
students were able to describe in a literary manner or scientifically, then analyze and interpret the structure of the Danube Delta ecosystems visible in the photo, so we matched the aims with the specific competences.

The questions in the first version were correct, but not enough to provide the description of the picture content. After the feedback provided by the professor, we realized that it could be the same questions in both tasks, but that in replying, it was necessary to use different styles: literary at first and scientifical at the second task.

The first descriptive texts, analytical texts and explanatory texts we did not strictly correlate to the questions, they were not systematic and complete, but only the texts written in the second variant, the one given at the results column.

In the first version of learning activity number three, we made up more aims than was needed for the aquisition of that specific competence. At the catechetical and the heuristic conversation, we made up some questions correctly, but there was no logical connection between them. Even if students answered correctly to them, we would not have been sure that they achieved the respective competence. The questions following the first and second feedback from the professor were more suitable for that.

At the learning activity number four, the first text also included information about the Danube Delta, in general, not only about the visible aspects of the photography. The first version of the text included the sequences of the informative text. The second was predominantly an explanatory text and provided more explanation about what was visible in the photo. The third explanatory text showed better and more systematically the connections between the photographed reality and the theory on ecosystems.

At the learning activity number five in the first version, we asked students to write in the first column everything seen in the photo, but in the second option we mentioned to write about the abiotic and the biotic components of the Danube Delta they observe in the photo. In the second version, we focussed also on writing the questions and answers to these.

In the sixth learning activity, the tasks corresponded to the six verbs written on the faces of the cube, but in the first version they were only partially related with the specific competence. In the first version of the learning activity number seven, students were given tasks correctly expressed, but partially related with the target competence. The tasks given to the students in the second version were correctly related to that specific competence and, by solving them, students contributed to its acqusition.

3) Analyzing the process performed for solving the given task.

At the learning activity number one, we had some difficulties in choosing the most appropriate terms that students should use when writing their descriptions. We chose, therefore, some terms that were not directly related to the content of the photo: population, hunting, fishing, tourism, importance, and swans. When writing the first drafts of descriptions, we were not very clear either about the procedures to follow when describing the content of the photo or about the criteria that texts should have observed. We understood subsequently that the task given acted as an 
initial testing of our skills to describe in a literary manner and scientifically what we saw in a photograph. After feedback from the professor, all these were more clear to us.

At the learning activity number two, when writing the questions in the study guide, we did not strictly aim at students noticing all aspects visible in the photo, because we thought that thats task complemented the first and we did not perceive it as a task used for directing the development of complete and accurate descriptions by students, a systematic and comprehensive analysis and interpretation of the issues identified in the analysis. In the first version of the descriptions, we did not aim at responding to questions in the order they were expressed, but we wrote down some descriptive texts, analytical texts, and also explanatory texts. We solved the tasks more accurately from students' perspective, taking into account the order, only after the professor asked us to count both questions and answers.

At the learning activity number three, we had difficulties in formulating the aims, since we were tempted to write more than necessary. Regarding the questions, only after feedback from the professor, we managed to provide logical questions that would adequately support students to identify components of ecosystems in the Danube Delta. Talking with the professor and classmates, we realized that to build a heuristic conversation it was necessary to have a high level of professional competence in the teaching of a specialization.

For the fourth learning activity, we were tempted to offer more information and explanations about the Danube Delta. The fact that in the photo were captured several ecosystems, increased the difficulty of explanation. It was quite difficult to explain systematically and completely both the structure of the ecosystems assembly and the structure of each ecosystem, independently.

At the learning activity number five, it was the first time we applied the method or model I know - I want to know - I'm learning for a photo. We were compelled that in the first column to have only information about what was represented in the photo, and the questions and answers from other columns to be related to the specific competence, the aims and the content of the photo.

At the sixth learning activity, we composed easily the tasks related to the keywords on each face of the cube. These tasks we partly linked to the specific competence, as the cube method required the use of certain verbs: to describe, to analyze, to compare, to apply, to associate, and to argue.

At the learning activity number seven, we easily made up the tasks in each quadrant, but in the first version, we took too little into account the competence to be achieved, because our attention was focused on the method.

4) Analyzing the progress made in the development of professional competence by performing these tasks

Concerning the development of the competence to design learning activities, we could notice an increase in the level of competence in linking the specific competence and aims to the subject or content of the activity, tasks, teaching methods and procedures, and to the activity itself. 
Concerning the development of the competence to analyze and also to interpret the content of a photo, we realized that there was an increase in the level of competence, as we systematically identified the visible components, we linked them to the theory of ecosystems, we understood their meaning and also the relationships between them (topological relations, nutrition relations, cause-effect relations, etc.).

Concerning the development of the competence to write different types of texts (descriptive, explanatory, informative, and a dialogue), we noticed an increase in the level of competence in that we managed to match the content of these texts with the content of the photo. We took into account the specific competence and the aims, the teaching methods and also the meaning and use of specialized terms (ecosystem, biotope, biocenosis, biotic element, abiotic elemen,t etc.).

5) Analyzing the transfer of the result of the learning activities and tasks into the school curriculum.

At the end of this study, we concluded that designing learning activities can be applied in the school curriculum, starting from a specific competence and linking it with certain operational objectives, to be very clear what students should learn.

We also noticed that in analyzing and interpreting the content of a photograph with the students, we can use various forms of organization or interaction, different teaching methods and procedures. However, we do not expect students to solve the tasks given to the level of competence of the teacher.

\section{References}

Academia Română. Institutul de Lingvistică din Bucureşti (1998). Dicționar explicativ al limbii române - DEX (ediția a II-a). București: Editura Univers Enciclopedic.

Academia Română. Institutul de Lingvistică din Bucureşti (2009). Dicționar explicativ al limbii române - DEX (ediția a III-a, revăzută și adăugită). București: Editura Univers Enciclopedic Gold.

Băban, A. (2002). Metodologia cercetării calitative. Cluj-Napoca: Editura Presa Universitară Clujeană.

Delta Dunării, Retrieved April 4 2014, from http://ro.wikipedia.org/wiki/Delta_Dun\%C4\%83rii

Marcu, F., \& Maneca, C. (1986). Dicționar de neologisme. București: Editura Academiei.

Ministerul Educaţiei, Cercetării şi Inovării (2009). Programe şcolare. Biologie. Clasele a V-a, a VI-a, a VII-a, a VIII-a. Bucureşti. Biology syllabus for the $8^{\text {th }}$ grade (Bucharest, 2009, Ministry of Education, Research and Innovation, School curricula, Biology, the $5^{\text {th }}$, the $6^{\text {th }}$, the $7^{\text {th }}$, and the $8^{\text {th }}$ grade) 
ROXANA TEODORA MATEIU (COTOI), LARISA CIUREAN, CODIN CIUREAN

Retrieved April 4 2014, from http://www.isjcta.ro/wpcontent/uploads/2013/11/biologie_5_8.pdf

NODEX - Noul dicționar explicativ al limbii române (2002). București: Editura Litera Internațional.

http://salvatidelta.ro/deltasemper 